\title{
Wetland Crops Versus Wetland Drainage
}

\author{
George H. Snyder ${ }^{1}$ and Christopher W. Deren ${ }^{2}$ \\ University of Florida, Everglades Research and Education Center, P.O. Box 8003, Belle Glade, FL 33430 \\ Barry Glaz ${ }^{3}$ \\ USDA/ARS Sugarcane Field Station, Star Rt. Box 8, Canal Point, FL 33438
}

\section{WETLAND DRAINAGE FOR AGRICULTURE}

Traditionally, wetlands have been drained to permit agricultural production. In the United States, perhaps the most extensive wetland to be drained is the Everglades in Florida. Starting with the time of statehood, and throughout the remainder of the 1800s and the early 1900 s, Florida sought to attract residents. The Everglades was viewed as a vast, uninhabitable wasteland that, if drained, could be the basis for new settlers and new wealth (Snyder and Davidson, 1994). Before the Civil War, a governmental report (Dovell, 1947) stated that:

"The Everglades are now suitable only for the haunt of noxious vermin, or the resort of pestilent reptiles. The statesman whose extensions shall cause the millions of acres they contain, now worse than worthless, to teem with the products of agricultural industry; that man who thus adds to the resources of his country ... will merit a high place in public favor, not only with his own generation, but with posterity. He will have created a state!".

Wetlands elsewhere have been similarly disparaged in their natural state, and touted as becoming an economic bonanza if drained. Even today, vast areas of tropical forest wetlands in southeast Asia are being drained for agricultural development (Driessen and Soepraptohardjo, 1974; Liong and Siong, 1979).

In Florida and throughout the nation, public sentiment now has shifted 180 degrees on Everglades drainage. Today, the drainage is viewed as an environmental disaster, even though nearly everything in terms of agricultural production and population growth that was hoped for in the 1800s has been realized. "Everglades restoration" is the public goal today, albeit that true restoration would mean reflooding hundreds of thousands of acres of not only farmlands, but of cities and suburbs as well. Mehallis et al. (1995) estimated that nearly $45 \%$ of Florida's population lives within the greater Everglades ecosystem, and it is estimated that more than 2 million persons in Southeast Florida live in areas that were historically part of the Everglades (Christine Harwell, Univ. of Miami, personal communication, 1997). Nevertheless, insofar as currently occupied land is flooded to achieve restoration, one can surmise that only farmland will be "restored"- a process that already has begun (Anonymous, 1997; Rozsa, 1995; Woodward, 1997).

Perhaps the United States has the wealth to solve its environmental problems/desires at the expense of agriculture. However, many other nations with severe environmental problems can ill afford to follow this model. Generally, only after the basic needs of a nation for food and shelter are met does the population become interested in enhancing or preserving the natural environment. Even with regard to the Everglades, the U.S. Dept. of State's Man and the Biosphere Program recently concluded that "restoration" should provide for the long-term security of both the ecological and agricultural systems of the region (Anonymous, 1994). In Florida, as well as in other regions of the

Received for publication 4 Feb. 1998. Accepted for publication 4 Feb. 1998. A contribution of the Florida Agricultural Experiment Station, Univ. of Florida, Gainesville. Florida Agricultural Experiment Station Journal Series No. R06654. The authors express their appreciation to Dr. Monika Reuter, Ms. Kathy Krawchuk, and Mr. Richard Lentini for assistance with manuscript preparation. The cost of publishing this paper was defrayed in part by the payment of page charges. Under postal regulations, this paper therefore must be hereby marked advertisement solely to indicate this fact.

${ }^{1}$ Professor.

${ }^{2}$ Professor.

${ }^{3}$ Agronomist.
United States and elsewhere, having an agriculture based on aquatic and/or water-tolerant crops in already altered and degraded wetlands may be preferable to either the status quo or wetland restoration with concomitant destruction of the region's agriculture.

\section{AGRICULTURAL UTILIZATION OF WETLAND RESOURCES}

Wetlands often function as filters or sinks, accumulating and storing certain elements and substances. Organic matter, for example, with its carbon, phosphorus, nitrogen, and sulfur, generally is higher in wetlands than in adjacent uplands. Water, of course, also is abundant. Upon drainage, not only water, but also nutrients and organic matter decrease substantially. The lost elements often are considered pollutants in the environments to which they are transported. In addition to these losses, considerable energy must be expended to resist the natural tendency of the region to accumulate water. An agriculture that utilizes the natural features of a wetland would be more efficient and environmentally compatible than one that requires a constant battle against the forces of nature (Porter et al., 1991).

\section{SUBSIDENCE OF ORGANIC SOILS}

In the Everglades, organic matter accumulation over 5000 years provided the parent material for most of the soils. Frequently, the soils contain over $85 \%(\mathrm{~m} / \mathrm{m})$ organic matter. When drained, these soils decompose (oxidize), resulting in their physical destruction and a lowering of the surface elevation (Fig. 1), termed "subsidence." As

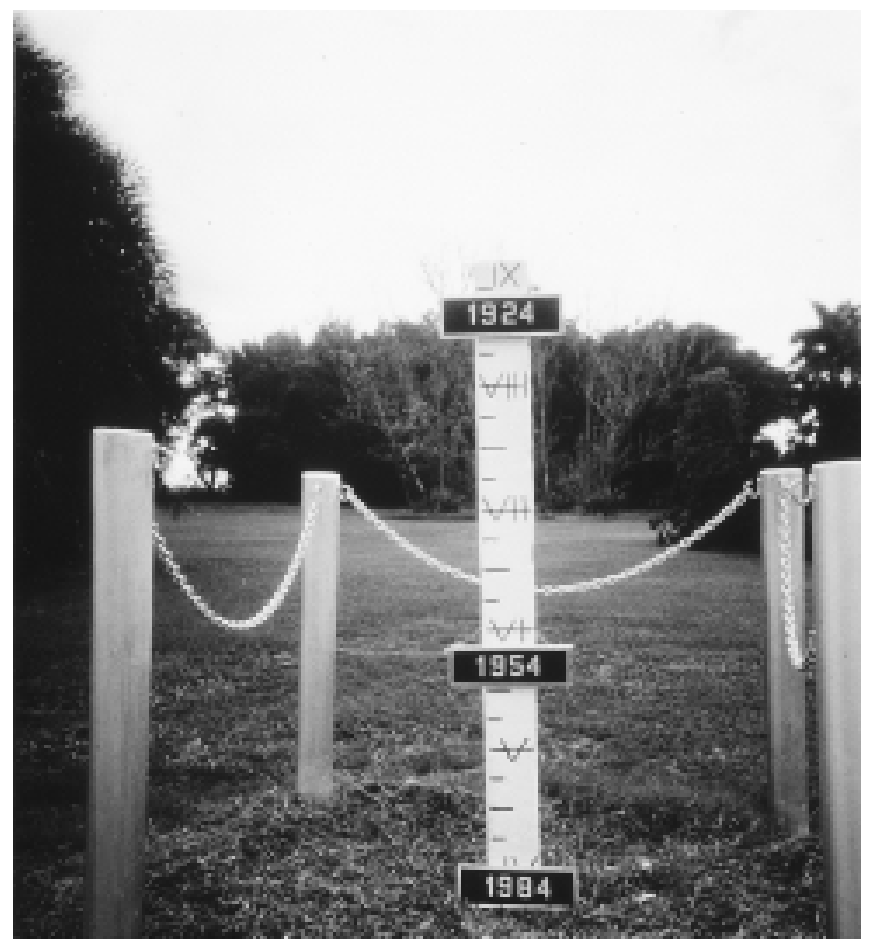

Fig. 1. A concrete post resting on bedrock illustrating the surface elevation of an organic soil in the Everglades at 30-year intervals. The units presented in Roman numerals are feet $(30 \mathrm{~cm})$ above bedrock. 
land elevations decline, increased energy is required to maintain drainage against the comparatively increasing hydraulic head of surrounding lands and bodies of water. Subsidence is not unique to the Everglades, for it follows whenever a highly organic soil is drained. However, it is an especially serious problem in the Everglades because the organic soils generally directly overlie hard limestone bedrock (Fig. 2) (Snyder, 1994). Thus, when the organic soils are gone, little will remain to support any agricultural production.

\section{A WETLAND-BASED AGRICULTURE}

Just as flooding created the organic soils, it is the only known practical practice that will stop the subsidence of organic soil. For this reason efforts have been made to develop a wetland-based agriculture (Morton and Snyder, 1976). Although the desire to stop subsidence has been the main goal of this work, additional benefits would include reducing both energy consumption and the downstream consequences of nutrient outflows. As an example of the latter, Morris (1975) estimated that subsidence generated $87 \mathrm{~kg} \cdot \mathrm{ha}^{-1}$ per year of $\mathrm{P}$, which is four times the average rate of $\mathrm{P}$ fertilization for sugarcane (Saccharum sp.) (Sanchez, 1990). Also, since the area would be better adapted to predrainage hydrologic conditions, it in turn could be more supportive of more pristine areas to the south by supplying water in more appropriate timing and quantity. A wetland agriculture should increase south Florida's water storage capability and reduce the immediate need to transport and store water following storms (Shih and Snyder, 1982). A wetter agriculture could also lead to interdisciplinary, on-farm research to make agricultural fields acceptable habitat for some threatened and endangered species. Already, an increase in Florida's resident waterfowl resource has been closely associated with the new rice industry in the region (Turnbull et al., 1989). The Everglades experiences probably cannot be directly adopted in other wetland regions. Nevertheless, they may provide inspiration and guidelines for what will be feasible, or illustrate ideas that are unsuitable, for other wetlands. This is especially important, since many view Everglades restoration as an international model.

\section{POTENTIAL WETLAND CROPS FOR SOUTH FLORIDA}

The climate of the Everglades consists of a cool, relatively dry winter and a hot, humid, summer rainy season. Over $75 \%$ of the annual

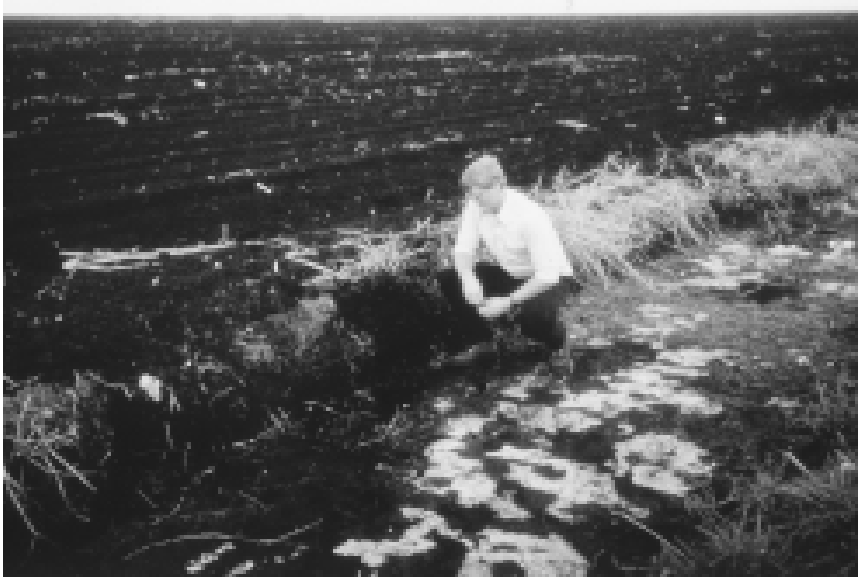

Fig. 2. Dr. Frank Coale standing on limestone bedrock that lies below a shallow organic soil in the Everglades. rainfall occurs from May through October, and total annual rainfall can vary considerably from year to year. For these reasons, an entire agricultural basin that always required flooding would sometimes be at odds with the natural hydroperiod. Also, such an agriculture would be difficult to support because nearby urban areas and the Everglades National Park would be first in line, ahead of farmers, to receive water during droughts. For this reason, only crops that can tolerate or benefit from flooding would best be suited as major crops in an Everglades agriculture, and those that must always be flooded as minor crops. For this reason, significant land area probably should not be cropped to such commodities as fish for food or for aquariums, or to aquarium/ pond plants. In addition, crops such as aquarium plants that could become major aquatic weed problems (Sutton and Vandiver, 1986) probably are unsuitable for production in the Everglades.

A variety of suitable food and feed wetland crops can be proposed. Some are tuber crops, such as taro (Colocasia esculenta Schott), which provides a high-quality, nonallergenic starch that can be used in a variety of foods (Moy and Nip, 1983). For example, taro chips, similar to potato chips, are commercially marketed (Fig. 3). The leaves are eaten as a green vegetable (de la Pena, 1970) and are routinely imported into Miami for that purpose. In addition to being consumed as a food, the tubers can be used as a biofuel (methane, ethanol) feedstock (Snyder and O'Hair, 1986). A mechanized taro tuber harvester developed by the Univ. of Hawaii functioned well in the organic soils of the Everglades. Taro can be grown either with or without flooding, making it suitable for environments with periodic water deficits.

Lotus (Nelumbo nucifera Gaertn.) is commercially grown in Japan (Fig. 4), Hong Kong, and southeast Asia for its rhizome, which is eaten as a vegetable (Morton and Snyder, 1976). Dried lotus rhizomes are sold in the United States. In addition to the rhizomes, rice is wrapped in lotus leaves and steamed to give it a "nutty" flavor. The flowers are large and beautiful, though short-lived. The seeds are eaten, and the dried seedheads often are used in flower arrangements. In fact, they are collected from the wild in Lake Okeechobee, on the north side of the Everglades. In our experience, lotus appears to require a fairly constant and deep (30 to $50 \mathrm{~cm}$ ) flood.

Chinese waterchestnuts [Eleocharis dulcis (Burm.) Trin.] are another tuber crop suitable for the Everglades (Morton et al., 1988). Millions of dollars worth of waterchestnuts are imported annually into the United States for use as an ingredient in salads and Chinese dishes. They grow readily during the summer in the Everglades environment,

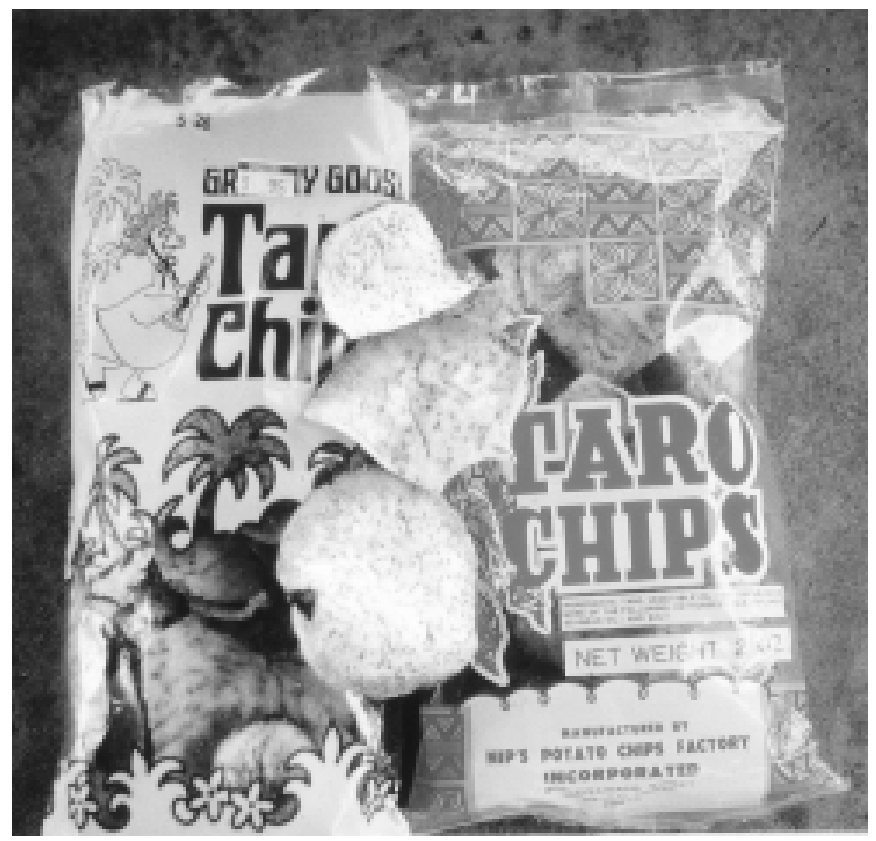

Fig. 3. Chips are one of several ways in which taro is processed for food. 


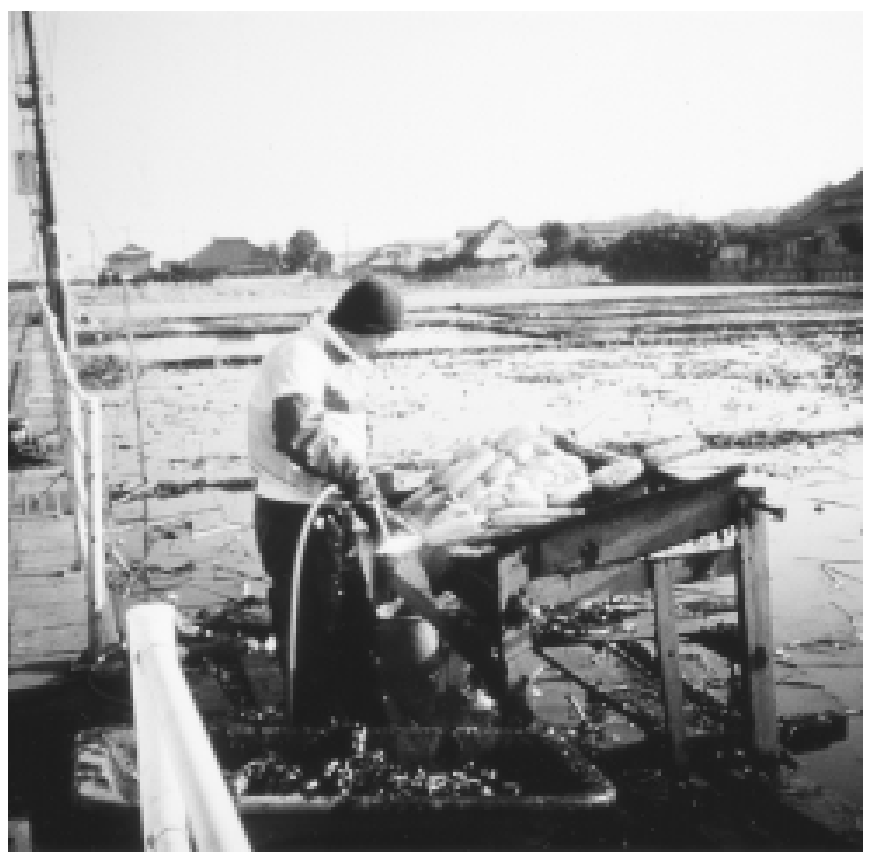

Fig. 4. Washing lotus rhizomes that were harvested from a flooded field in Japan.

but constant flooding is required for good growth. Unfortunately, mechanized harvesting equipment is not commercially available.

A variety of leafy aquatic vegetables is consumed worldwide. For example, water spinach [Ipomoea aquatica Forsk. (I. reptans Poir.)] is a nutritious, tropical vegetable widely grown in southeast Asia. In Hong Kong, it is grown during the summer in rotation with watercress (Nasturtium officinale $\mathrm{R}$. Br.), a cool-season aquatic vegetable that is grown commercially during the winter in south Florida, though not at present in the Everglades. Water spinach grows well in south Florida (Snyder et al., 1981). However, concerns about the invasive weed potential of water spinach have placed it on Florida's list of prohibited plants, although it is grown on many small farms and can be found periodically as a fresh vegetable in Florida oriental food markets. It grows well in a shallow flood or in wet, but unsaturated, soil. In deeper floods, it can be grown on floating trays. Water celery [Oenanthe javanica (B1.) DC.] is a flavoring herb that grows well in the Everglades and has been marketed successfully in a south Florida supermarket (Morton and Snyder, 1978). Like water spinach, water celery can be grown both in a shallow flood, or in moist soil, and appears to be considerably more frost-tolerant than water spinach.

Several water-tolerant forages have been studied in the Everglades. Considerable animal feed is imported into south Florida for the extensive horse (racing, polo, jumping, rodeo, and recreational) industry and for dairy farms. Yet little forage (hay, silage) is produced locally, even though the Everglades wetland provides the ingredients (water, temperature) for excellent year-round production. Based on the senior author's observations, alemangrass [Echinochloa polystacha (HBK) A. Hitchc.] appears to be especially suitable as a high yielding, nutritious, wetland forage crop (Fig. 5).

A number of biomass crops can be grown under flooded conditions. Biomass may be converted to methane or methanol, or burned directly to produce energy. Currently, there are two plants for generating electricity in the Everglades Agricultural Area (EAA) that burn sugarcane by-products for part of the year, and require additional fuel when that supply is exhausted. Grasses with biomass and biochemical potential, such as Saccharum hybrids, have been shown to grow well even when flooded during the traditional rainy season (Deren et al., 1991b). Wood crops such as baldcypress [Taxodium distichum (L.) Rich.], or even certain cultivars of eucalyptus (Eucalyptus spp.), also are potential wetland fuel sources, and can be used for traditional timber products (Rockwood et al., 1994).

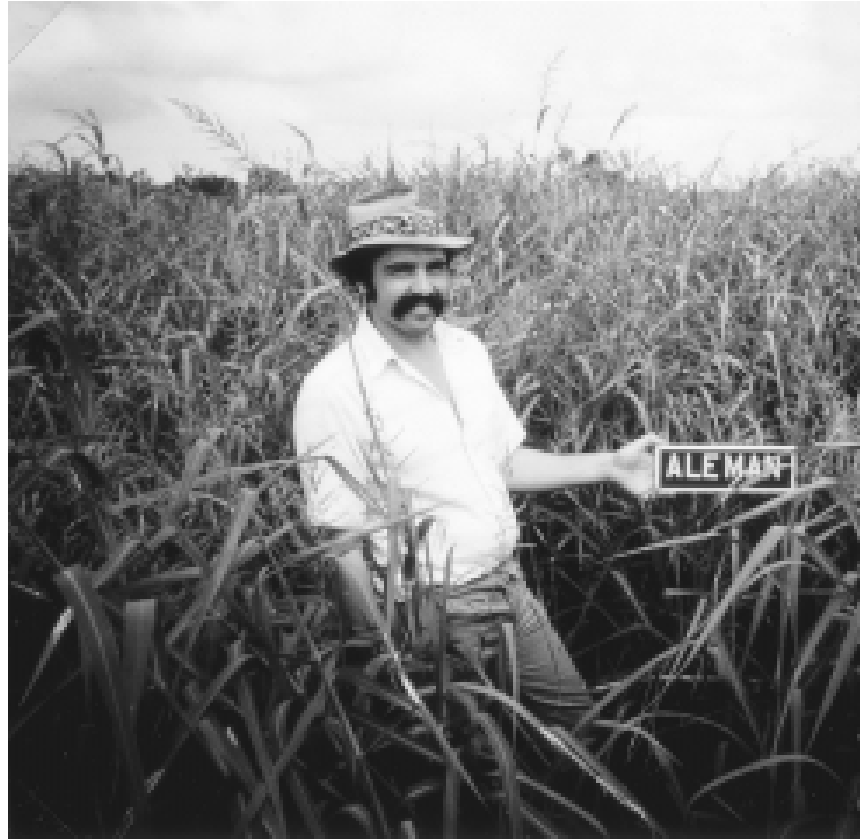

Fig. 5. Dr. Charlie Sanchez standing in a lush growth of alemangrass in an Everglades flooded field.

\section{ACCEPTANCE OF WETLAND CROPS IN THE EVERGLADES}

Each of the aforementioned crops can be produced in the Everglades, yet none has become commercially accepted. Most of the farmland in the Everglades is owned and used for sugarcane production by large corporations that have large financial investments in sugarcane. Since sugar production is profitable, land is not converted to unproven wetland crops, even though doing so probably would extend the life of the organic soils. In addition, crops that require considerable manual labor often are not as well suited to highly mechanized, corporate agriculture. These crops may gain favor in the future, and can be utilized now by the few small landholders who are less encumbered by tradition, investment, and bureaucracy. Nevertheless, the potential exists for a more aquatic-based agriculture in the Everglades, even with the current farming structure.

Rice (Oryza sativa L.) has become a commercially viable wetland crop in the EAA over the past 20 years (Alvarez et al., 1989). Although only $\approx 10,000$ ha of rice are grown at present, there is potential for much greater production without displacing the principal crop, sugarcane, and without having a major impact on U.S. rice prices. Sugarcane biomass and sugar yields have been shown to increase in plantings that follow a rice crop (Alvarez and Snyder, 1984). Rice culture reduces soil-insect populations (Cherry, 1987), and rice production is part of various scenarios that have been proposed to enhance the Everglades ecosystem (Deren et al., 1995, Glaz, 1995). Wild rice (Zizania palustris L.) also can be grown in the Everglades (Morton and Snyder, 1980). However, cultivars adapted to south Florida, and particularly to the region's relatively short summer days, are needed.

Even sugarcane, which is, by far, the principal crop grown in the EAA, has potential for being grown under wetland conditions. Some sugarcane cultivars survived extensive flooding following a major hurricane in 1928, and the descendants of these cultivars are grown today. Some of them produce fairly well in spite of seasonal flooding (Fig. 6), and it may be possible to develop even more flood-tolerant cultivars (Deren et al., 1991b). Glaz (1995) described a research program whose goal was to take advantage of the water tolerance already in sugarcane and gradually improve it so that basinwide, a sugarcane-rice agriculture would be profitable under natural hydrological conditions.

With rice and sugarcane as the foundation, in addition to a variety of vegetable, animal feed, and biomass crops, the possibility exists for 


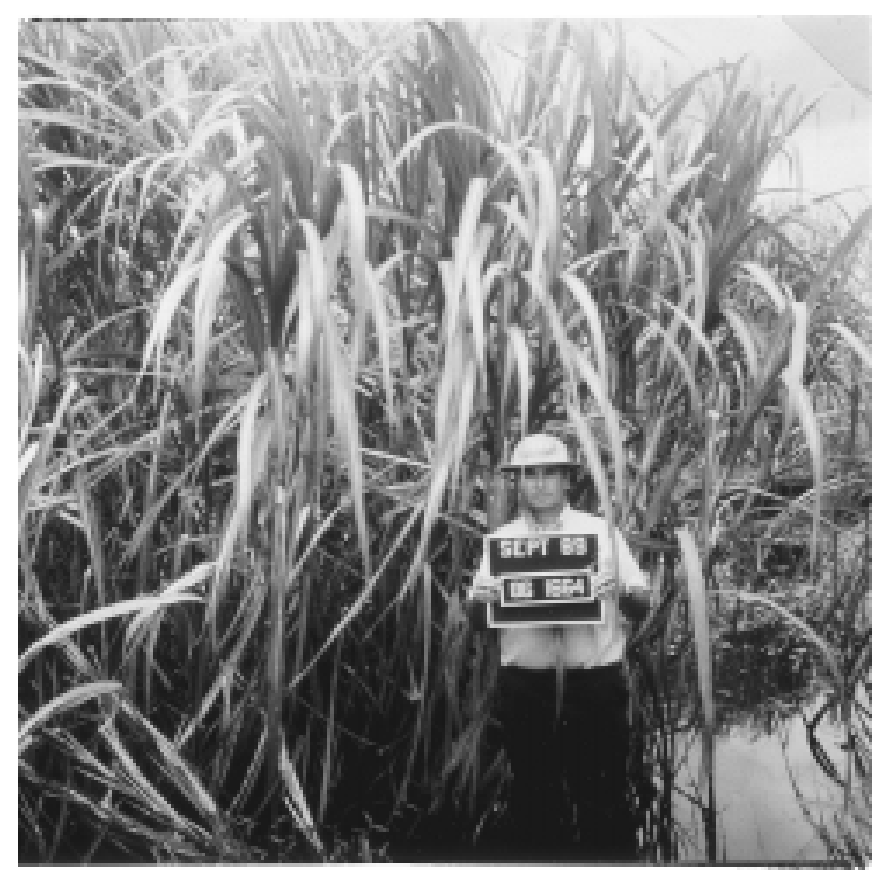

Fig. 6. Dr. George Snyder standing in second-year (ratoon) growth of a sugarcane selection that was flooded each year from July through November

a wetland-based agriculture in the Everglades that would provide both agricultural industry and ecological benefits. Other regions in the world, which either already have drained extensive areas of wetlands or are contemplating such projects, might be wise to consider the economic and ecological drawbacks to wetland drainage and to determine whether a wetland-based agriculture would provide for both agricultural and ecological sustainability.

\section{Literature Cited}

Alvarez, J. and G.H. Snyder. 1984. Effect of prior rice culture on sugarcane yields in Florida. Field Crops Res. 9:315-321.

Alvarez, J., G.H. Snyder, and D.B. Jones. 1989. The integrated program approach in the development of the Florida rice industry. J. Agr. Educ. 18:6-11.

Anonymous. 1994. Isle au Haut principles: Ecosystem management and the case of south Florida. Department of State Publication 10192, U.S. MAB Secretariat, OES/EGC/MAB, U.S. Dept. State, Washington, D.C.

Anonymous. 1997. District approves first purchase of non-STA land for Everglades restoration. The Sun (Belle Glade, Fla.) 74(1):1. Jan. 23.

Cherry, R.H. 1987. The effect of flooding on insect populations, p. 27-34. In: G.H. Snyder (ed.). Agricultural flooding of organic soils. Florida Agr. Expt. Sta. Tech. Bul. 870.

de la Pena, R.S. 1970. The edible aroids in the Asian-Pacific area. Proc. 2nd Intl. Symp. on Trop. Root and Tuber Crops vol. 1, p. 136-140.

Deren, C.W., B. Glaz, and G.H. Snyder. 1995. Wetland agriculture in the Everglades: A concept for sustaining agriculture and the ecosystem, p. 3543. In: K.L. Campbell (ed.). Proc. Intl. Conf. on Versatility of Wetlands in Agricultural Landscapes. Amer. Soc. Agr. Eng.

Deren, C.W., G.H. Snyder, J.D. Miller, and P.S. Porter. 1991a. Screening for and heritability of flood-tolerance in the Florida (CP) sugarcane breeding population. Euphytica 56:155-160.
Deren, C.W., G.H. Snyder, P.Y.P. Tai, and D.B. Chynoweth. 1991b. Biomass production and biochemical methane potential of seasonally flooded intergeneric and inter-specific Saccharum hybrids. Bioresource Tech. 36:178-184.

Dovell, J.E. 1947. A history of the Everglades in Florida. PH Diss., Univ. of North Carolina, Chapel Hill.

Dreissen, P.M. and M. Soepraptohardjo. 1974. Soils for agricultural expansion in Indonesia. Bul. 1, Soil Res. Inst., Bogor, Indonesia.

Glaz, B. 1995. Research seeking agricultural and ecological benefits in the Everglades. J. Soil and Water Conserv. 50:609-612.

Liong, T.Y. and K.H. Siong. 1979. A Review of lowland organic soils of Sarawak. Tech. Paper No. 4, Res. Branch, Dept. Agr., Sarawak, Malaysia.

Mehallis, M., L. Berry, K. Thai, C. Murphy, and S. Senjo. 1995. Regional structural change: A south Florida profile. Monograph. Florida Atlantic Univ., Boca Raton.

Morris, T. 1975. Everglades agricultural area backpumping study, p. 346-419. In: F.G. Norddie and T. Gayle (eds.). Water quality models for understanding potential eutrophication in Lake Okeechobee, Florida. Center for Wetlands, Univ. of Florida, Gainesville.

Morton, J.F., C.A. Sanchez, and G.H. Snyder. 1988. Chinese waterchestnuts in Florida-Past, present, and future. Proc. Fla. State Hort. Soc. 101:139-144.

Morton, J.F. and G.H. Snyder. 1976. Aquatic crops vs. organic soil subsidence. Proc. Fla. State Hort. Soc. 89:125-129.

Morton, J.F. and G.H. Snyder. 1978. Trial of water celery as an aquatic flavoring herb for Everglades farmlands. Proc. Fla. State Hort. Soc. 91:301-305.

Morton, J.F. and G.H. Snyder. 1980. Wild rice-A promising gourmet crop for the Everglades. Proc. Fla. State Hort. Soc. 93:273-278.

Moy, J.H. and W.K. Nip. 1983. Processed food, p. 261-268. In: J.K. Wang (ed.). Taro, A review of Colocasia esculenta and its potential. Univ. of Hawaii Press, Honolulu.

Porter, P.S., G.H. Snyder, and C.W. Deren. 1991. Flood-tolerant crops for low input sustainable agriculture in the Everglades Agricultural Area. J. Sustainable Agr. 2:77-101.

Rockwood, D.L., G.H. Snyder, and R.R. Sprinkle. 1994. Woody biomass production in waste recycling systems, p. 351-358. In: Proc. 6th Natl. Bioenergy Conf. vol. 1.

Rozsa, L. 1995. Farmers sell the Frog Pond. Miami Herald, Section B., 22 Feb., p. 1B, 3B.

Sanchez, C.A. 1980. Soil-testing fertilization recommendations for crop production on organic soils in Florida. Florida Agr. Expt. Sta. Tech. Bul. 876.

Shih, S.F. and G.H. Snyder. 1982. Water control and cropping alternatives in the Everglades, p. 149-158. In: E.C. Kruse, C.R. Burdick, and Y.A. Yousef (eds.). Environmentally sound water and soil management, Amer. Soc. Civil Eng., New York.

Snyder, G.H. 1994. Soils of the EAA, p. 292-304. In: A.B. Bottcher and F.T. Izuno (eds.). Everglades Agricultural Area (EAA): Water, soil, crop, and environmental management. Univ. Press of Florida, Gainesville.

Snyder, G.H. and J.M. Davidson. 1994. Everglades Agriculture: Past, present, and future, p. 85-115. In: S.M. Davis and J.C. Ogden (eds.). Everglades, the ecosystem and its restoration. St. Lucie Press, Delray Beach, Fla.

Snyder, G.H., J.F. Morton, and W.G. Genung. 1981. Trials of Ipomoea aquatica, nutritious vegetable with high protein and nitrate-extraction potential. Proc. Fla. State Hort. Soc. 94:230-235.

Snyder, G.H. and S.K. O'Hair. 1986. Biomass production from Taro (Colocasia esculenta) in subtropical wetlands, p. 185-196. In: W.H. Smith (ed.). Biomass energy development. Plenum Press, New York.

Sutton, D.L. and V.V. Vandiver, Jr. 1986. Grass carp: A fish for biological management of hydrilla and other aquatic weeds in Florida. Florida Agr. Expt. Sta. Bul. 867.

Turnbull, R.E., F.A. Johnson, and D.H. Brakhage. 1989. Status, distribution, and foods of fulvous whistling-ducks in south Florida. J. Wildlife Mgt. 53:1046-1051.

Woodward, C. 1997. President's budget: Early gain, later pain. The Palm Beach Post, 7 Feb., p. 1A, 8A. 